\title{
An Analysis of Biogas Reforming Process on Ni/YSZ and Ni/SDC Catalysts"
}

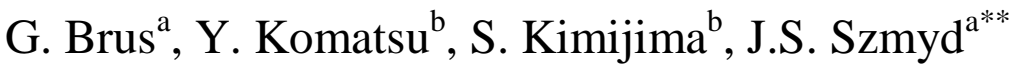 \\ ${ }^{a}$ AGH University of Science and Technology, Krakow, Poland \\ ${ }^{\mathrm{b}}$ Shibaura Institute of Technology, Tokyo, Japan \\ E-mail: janusz@agh.edu.pl
}

\begin{abstract}
The conversion of biogas to electricity presents an attractive niche application for fuel cells. Thus attempts have been made to use biogas as a fuel for high temperature fuel cell systems such as SOFC. Biogas can be converted to hydrogen-rich fuel in a reforming process. For hydrocarbon-based fuel, three types of fuel conversion can be considered in reforming reactions: an external reforming system, an indirect internal reforming system and a direct internal reforming system. The possibility of using internal reforming is one of the characteristics of high temperature fuel cells like SOFC. However, for high-temperature operation, thermal management of the SOFC system becomes an important issue. To properly carry out thermal management, both detailed modeling and numerical analyses of the phenomena occurring inside the SOFC system are required. In the present work, the process of reforming biogas on a $\mathrm{Ni} / \mathrm{YSZ}$ and a $\mathrm{Ni} / \mathrm{SDC}$ catalyst has been numerically and experimentally investigated. Measurements including different thermal boundary conditions, steam-to-carbon ratios and several different fuel compositions were taken. A numerical model containing methane/steam reforming reaction, dry reforming reaction and shift reaction has been proposed to predict the gas mixture composition at the reformer outlet. The results of numerical computation were compared with experimental data and good agreement has been found. The results indicate the importance of combined numerical and experimental studies in the design of SOFC reformers. The combined approach used here leads to the successful prediction of the outlet gas composition for different modeling conditions.
\end{abstract}

Keywords: Biogas reforming; dry reforming; Ni/SDC catalyst; methane/steam reforming.

\section{Introduction}

Biomass is of particular interest as a viable energy source. Thus attempts have been made to use biogas produced from the anaerobic digestion of biomass as a fuel for high-temperature fuel cell systems such as SOFC. Biogas, mostly consisting of methane $\left(\mathrm{CH}_{4}\right)$ and carbon dioxide $\left(\mathrm{CO}_{2}\right)$, is a potentially clean and renewable energy source. The high working temperature of SOFC allows for a wide range of hydrocarbon-based fuels, including biogas, to be fed directly into the system while omitting complex and expensive external reforming. For hydrocarbon-based fuel, two types of internal conversion can be considered in the reforming reactions: direct internal reforming and indirect internal reforming. Because both indirect and direct internal reforming are carried out at high temperatures, thermal management becomes an important issue. However, to do it properly, detailed modeling and numerical analyses of the phenomena occurring inside the reformer are required. The use of biogas in a small tubular SOFC unit was studied in the past (Thyberg and Myrkn, 1995; Staniforth and Kendall, 1998). High yields of hydrogen from biogas were obtained at relatively low temperatures and low steam-to-carbon ratios. The large carbon dioxide content of biogas enhances hydrogen production, which makes biogas a suitable fuel for fuel-cell power plants (Thyberg and Myrkn, 1995). The results by J. Staniforth and Kendall (1998) show that biogas is a suitable fuel for high-temperature fuel cells even when the methane content was below the value at which normal combustion can occur (20\% methane to carbon dioxide). They also showed that the formation of carbon is a major problem during the biogas reforming process and must be minimized (Thyberg and Myrkn, 1995; Staniforth and Kendall, 1998). To do so, both the thermal management and catalyst material must be taken into consideration. They also discovered that by replacing $\mathrm{Ni}$ with a noble metal such as $\mathrm{Rh}, \mathrm{Ru}, \mathrm{Pd}, \mathrm{Ir}$ and $\mathrm{Pt}$, coke formation could be reduced (Berman et al., 2005). Because of the relatively high prices of noble metals, their application is limited. It was reported (Brandon. and Thompsett, 2005; Murray et al., 1999) that $\mathrm{Ni}$ supported on Samarium-doped Ceria (SDC) is an effective catalyst material for the suppression of carbon deposition. This allows the utilization of methane-rich fuels with a low steam-to-carbon ratio. Additionally, ceria oxide based materials exhibit catalytic properties for a number of reactions, including water-gas shift and steam reforming (Brandon and Thompsett, 2005; Tsang et al., 1995). Therefore Ni/SDC catalyst fulfills the requirements as a catalyst material for reforming biofuels, where protecting the catalyst from carbon formation is a key consideration. Due to its use in thermal management, the numerical analysis of biogas reforming was studied in the past (Nishino and Szmyd, 2008; Komatsu et al., 2009). Nishino and Szmyd (2008) assumed that a dry reforming reaction

${ }^{*}$ This paper is an updated version of a paper published in the ECOS'10 proceedings. It is printed here with permission of the authors and organizers. 
can be included in the numerical model indirectly via backward reaction of carbon monoxide with steam (shift reaction). They carried out a numerical study on the thermal and electrochemical characteristics of a tubular solid oxide fuel cell (T-SOFC), employing the steam reforming of biogas in each individual cell unit but indirectly from the anode. It was also shown that for a $\mathrm{CO}_{2}$-rich fuel, temperature gradients within the cell decrease as the proportion of $\mathrm{CH}_{4}$ in the inlet fuel gas is reduced (Nishino and Szmyd, 2008). This is a promising observation for the future use of biogas-based fuel cell systems. Based on Nishino's work (Nishino and Szmyd, 2008), Komatsu (Komatsu et al., 2009) conducted a numerical analysis of system performance for a Solid Oxide Fuel Cell (SOFC) Micro Gas Turbine (MGT) hybrid power system using biogas. It was found that a larger cell active area was required while the $\mathrm{CH}_{4}$ concentration diluted. The results are promising for the future application of biogas in SOFCMGT hybrid systems (Komatsu et al., 2009). A system analysis of an SOFC unit run on biogas has been studied by Van Herle (Van Herle et al., 2004). A model for a 100kW class solid oxide fuel cell (SOFC) system running on biogas from a sewage sludge digestion plant was implemented. The analysis showed that an SOFC module run on biogas containing $63 \% \mathrm{CH}_{4}$ and $35 \% \mathrm{CO}_{2}$ can be successfully used for a small heat and power unit. It was indicated that using biogas in the SOFC unit can significantly contribute to a $\mathrm{CO}_{2}$ reduction strategy (Van Herle et al., 2004). While most of the previous studies on the biogas reforming process focus on experimental or numerical analyses separately, there is a need for research on biogas reforming processes, including a comparison of experimental and numerical simulations. In the present work the reforming process of biogas on $\mathrm{Ni} / \mathrm{SDC}$ catalyst has been numerically and experimentally investigated.

\section{Experimental Investigation}

\subsection{Experimental procedure}

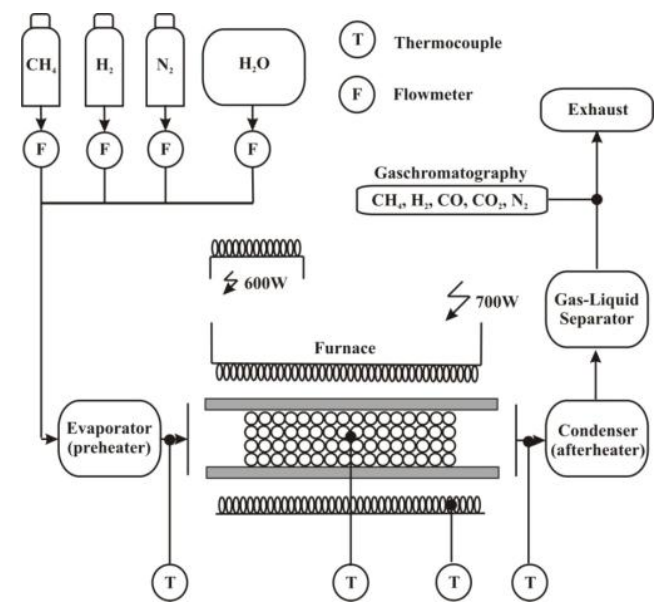

Figure 1. Schematic view of the experimental set-up.

A schematic view of the experimental setup is shown in Figure 1. A stainless steel reformer was placed in an electrical furnace, which can be heated up to $800^{\circ} \mathrm{C}$. The maximum working temperature of pre-heater and postheater is $400^{\circ} \mathrm{C}$; however, for all experimental investigations presented in this paper, the temperature of pre- and post-heater was maintained at $200^{\circ} \mathrm{C}$. Pre and post heating was used to avoid large temperature gradients inside the reactor. High purity methane-the fuel used in the experiment-was supplied to the reformer via a flow controller and an evaporator, which was also used as the pre-heater. Water was fed to the system with a pump.

The gas composition after the reforming process was analyzed by gas chromatography prior to which the steam had been separated by cooling down the gas mixture to $2^{\circ} \mathrm{C}$. Dew-point temperature of the product is around $40-50{ }^{\circ} \mathrm{C}$ at the atmosphere condition in this case of $S / C$ of 2.5 . Assuming the cooling temperature of the reformed gas at 5 ${ }^{\mathrm{O}} \mathrm{C}$ partial pressure of the steam reached approximately $1 / 10$ of the one before the condensing process. For cooling temperature set at $2{ }^{\circ} \mathrm{C}$ about $90 \%$ of steam contained in the reformed gas can be condensed, where the water content still stays as a state of the liquid. The cooling temperature must be designed to avoid the case where mechanical failure can occur due to the appearance of ice in the atmosphere path. In this way, the setting at $2{ }^{\mathrm{O}} \mathrm{C}$ can have a margin from the setting at $5{ }^{\circ} \mathrm{C}$ to make sure about $90 \%$ of the water condensed, at the same time still has a distance from the mechanical failure as mentioned in the last sentence. In addition to the viewpoint, regarding the separation of gas contents in the gas chromatography, remaining water content does not affect the result of mass spectrometry analysis. Water pump and evaporator accuracy have been investigated based on repeatability of steam flow rate at the outlet of reactor when reaction is not occurring. The repeatability of steam flow rate was found to be $+/-4 \%$. Regarding the separation of gas contents in the gas chromatography, the remaining steam content does not affect the result of mass spectrometry analysis directly. The steam content affects the dry mixture indirectly by changing the conversion rate, however, previously published data and author measurements indicate that steam content affect conversion rate strongly only for very small steam-to-methane ratio below 2. For steam to carbon ratios above 2.5 even for changing SC ratio more than 0.5 the change in conversion rate was not significant. Two methods of gas detection were used: TCD (Thermal Conductivity Detector) for carbon monoxide and carbon dioxide and FID (Flame Ionization Detector) for methane and hydrogen. The reforming reaction tube was partially filled with catalyst and partially with $\mathrm{Al}_{2} \mathrm{O}_{3}$, (elaborated in subsequent sections). To prevent large temperature gradients in the reformer, modifications to the reaction tube were applied. To avoid a cooling effect of the entering fluid, the reformer was partially filled with $\mathrm{Al}_{2} \mathrm{O}_{3}$, as shown in Figure 2B (Specification of the reactor properties are also listed in Table 1). In this solution, a mixture of gases before getting to the reaction zone was pre-heated by an electric furnace to the reaction temperature. To control the thermal conditions of the experiment, four thermocouples were located in the experimental set-up, as shown in Figure 1 (marked as "T"). To derive correct kinetics data, the reaction has to occur in the entire volume of catalyst. This can be accomplished by maintaining the reforming conversion rate at a low level. To achieve a low level of methane conversion, the fuel was additionally mixed with nitrogen (see Figure 2B). Nitrogen does not have a direct influence on the reforming reaction but the partial pressure of the components changed, which results in a decrease in both the reaction and methane conversion rates. All measurements presented in this paper have been performed at atmospheric pressure. 


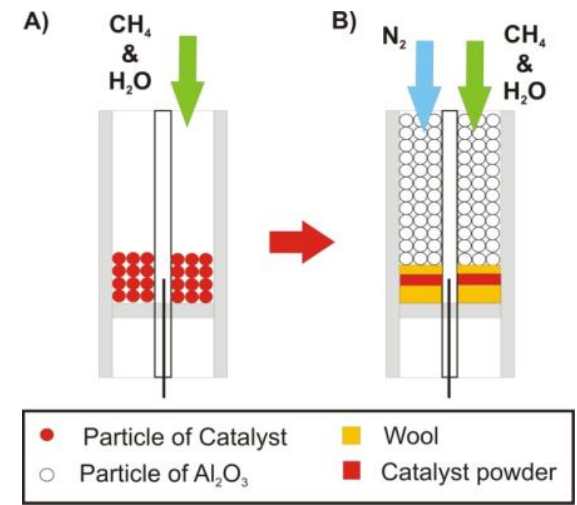

Figure 2. Schematic view of the reaction tube. A) Typical reaction tube. B) Modified reaction tube.

Table 1. Reactor properties.

\begin{tabular}{c|ccc} 
Type & Bed height & Radius & Length \\
\hline stainless steel & $1 \mathrm{~mm}$ & $25.4 \mathrm{~mm}$ & $450 \mathrm{~mm}$
\end{tabular}

\subsection{Catalyst preparation}

Two different support materials were used in the experimental investigation, SDC and Yttria-stabilized Zirconia (YSZ). The detailed catalysts properties are shown in Table 2. The catalyst powder used in the experiment is spherical in shape and has a $0.96-\mu \mathrm{m}$ diameter with specific surface area of $4.4 \mathrm{~m}^{2}$ per $1 \mathrm{~g}$ of catalyst for Ni/SDC and has a $0.85-\mu \mathrm{m}$ diameter with specific surface area of $5.2 \mathrm{~m}^{2}$ per $1 \mathrm{~g}$ of catalyst for Ni/YSZ (AGC SEMI CHEMICAL $\mathrm{CO}, 2009)$. Both of the catalyst materials were treated at the evaluated temperature of $800^{\circ} \mathrm{C}$ with a mixture of 150 $\mathrm{ml} / \mathrm{min}$ nitrogen and $100 \mathrm{ml} / \mathrm{min}$ hydrogen due to the reduction process of $\mathrm{NiO}$. $\mathrm{NiO}$ supported on YSZ has been kept in the reduction process for $6 \mathrm{~h}$. However, in case of $\mathrm{NiO}$ supported on $\mathrm{SDC}, 800^{\circ} \mathrm{C}$ is also the characteristic temperature of cerium oxide reduction. This process is very slow and according to already published data can take over $48 \mathrm{~h}$. Under reducing conditions a large amount of oxygen vacancies within the ceria material can be formed (the ceria ions $\mathrm{Ce}^{4+}$ are converted into $\mathrm{Ce}^{3+}$ and the oxygen vacancy is formed (Molenda et al., 2007)). Therefore the entire reduction process for $\mathrm{NiO}$ supported on SDC can be described by the following formulas:

Reduction of nickel oxide

$$
\mathrm{NiO} \rightarrow \mathrm{Ni}+\frac{1}{2} \mathrm{O}_{2}
$$

Reduction of Samarium-doped ceria

$$
\mathrm{Ce}_{0.8} \mathrm{Sm}_{0.2} \mathrm{O}_{1.9} \rightarrow \mathrm{Ce}_{0.8} \mathrm{Sm}_{0.2} \mathrm{O}_{1.9-\delta}+\frac{\delta}{2} \mathrm{O}_{2}
$$

Table 2. Catalyst properties (AGC SEMI CHEMICAL CO, 2009).

\begin{tabular}{c|cccc} 
Type & $\begin{array}{c}\text { Ni } \\
\text { contain }\end{array}$ & $\begin{array}{c}\text { Particle } \\
\text { size }\end{array}$ & $\begin{array}{c}\text { Active } \\
\text { area }\end{array}$ & Mass \\
\hline $\mathrm{Ni} / \mathrm{YSZ}$ & $60 \mathrm{vol} \%$ & $0.85 \mu \mathrm{m}$ & $5.2 \mathrm{~m}^{2} / \mathrm{g}$ & $1.5 \mathrm{~g}$ \\
$\mathrm{Ni} / \mathrm{SDC}$ & $60 \mathrm{vol} \%$ & $0.96 \mu \mathrm{m}$ & $4.4 \mathrm{~m}^{2} / \mathrm{g}$ & $1.5 \mathrm{~g}$
\end{tabular}

\subsection{Methane/Steam Reforming Kinetics on Ni/SDC Catalyst}

The methane/steam reforming process is widely known as a conventional process for producing hydrogen ( $\mathrm{Xu}$ and Froment., 1989). The main reaction that occurs during such a process can be represented by (3) and (4):

Methane steam reforming:

$$
\mathrm{CH}_{4}+\mathrm{H}_{2} \mathrm{O} \rightarrow 3 \mathrm{H}_{2}+\mathrm{CO}
$$

Shift reaction:

$$
\mathrm{CO}+\mathrm{H}_{2} \mathrm{O} \rightleftarrows \mathrm{H}_{2}+\mathrm{CO}_{2}
$$

It follows from the stoichiometry of the steam/methane reforming reaction that the reaction rate expression can be approximated with this equation:

$r_{\mathrm{st}}=k\left(p_{\mathrm{CH}_{4}}\right)^{a}\left(p_{\mathrm{H}_{2} \mathrm{O}}\right)^{b}$

where $k=A \exp (-E / R T), k$ is the reforming reaction constant, $p_{\mathrm{CH} 4}$ and $p_{\mathrm{H} 2 \mathrm{O}}$ are partial pressures in $\mathrm{Pa}$ of methane and steam, respectively, $a$ and $b$ are the dimensionless coefficients responding to the reaction order, $A$ is the pre-exponential factor, $E$ is the activation energy in $\mathrm{J} / \mathrm{mol}, R$ is the universal gas constant in $\mathrm{J} /(\mathrm{mol} \cdot \mathrm{K})$ and $T$ is the reaction temperature in $\mathrm{K}$. The non-equilibrium reaction for the plug-flow reactor rate can be described as a ratio between the change in the flow rate of methane and the change in the amount of catalyst (Vannice, 2005). Mathematically, this is written as

$r_{\mathrm{st}}=-\mathrm{d} F_{\mathrm{CH} 4} / \mathrm{d} w_{\mathrm{cat}}$

where $F_{\mathrm{CH} 4}=F^{\mathrm{in}}{ }_{\mathrm{CH} 4} \cdot(1-x), F_{\mathrm{CH} 4}^{\mathrm{in}}$ is the methane flow rate in $\mathrm{mol} / \mathrm{s}$ and $x$ is a dimensionless amount of reacted methane in the reforming reaction, and $w_{\text {cat }}$ is the weight of catalyst used, in $\mathrm{kg}$.

By combining Eqns (5) and (6), the following equation was formulated:

$k=\left(F_{\mathrm{CH}_{4}}^{\mathrm{in}} / w_{\text {cat }}\right) \cdot \int_{0}^{x_{\text {out }}}\left[\frac{1}{\left(p_{\mathrm{CH}_{4}}\right)^{a}\left(p_{\mathrm{H}_{2} \mathrm{O}}\right)^{b}}\right] \cdot d x$

From the stoichiometry of reactions (3) and (4), the partial pressures can be defined as

$$
p_{\mathrm{CH}_{4}}=\left(\frac{n_{\mathrm{CH}_{4}}}{n_{\mathrm{all}}}\right) \cdot P=\left[\frac{(1-x)}{(1+S C+N C+2 x)}\right] \cdot P
$$

$p_{\mathrm{H}_{2} \mathrm{O}}=\left(\frac{n_{\mathrm{H}_{2} \mathrm{O}}}{n_{\text {all }}}\right) \cdot P=\left[\frac{(S C-x-y)}{(1+S C+N C+2 x)}\right] \cdot P$

where $n_{\text {all }}$ is the total amount of product at the outlet of the reaction tube, $P$ is total pressure in $\mathrm{Pa}, n_{\mathrm{CH} 4}, n_{\mathrm{H} 2 \mathrm{O}}$ are, respectively, the methane and steam fractions at the reformer output, $x$ is a fraction of reacted methane, $y$ is a fraction of reacted carbon monoxide, $S C$ is the steam-to- 
carbon ratio and $N C$ is the nitrogen-to-carbon ratio. $n_{\text {all }}$ was derived from stoichiometry of reactions (3) and (4).

Introducing Eqns (8) and (9) into Eqn (7) yields the final form of the equation for the reaction constant:

$k=\left(\frac{F_{\mathrm{CH}_{4}}^{\mathrm{in}}}{w_{\text {cat }}}\right) \cdot \int_{0}^{x_{\text {out }}}\left(\frac{(1+S C+N C+2 x)^{a+b}}{P^{a+b}(1-x)^{a}(S C-x-y)^{b}}\right) \cdot d x$

where $a$ and $b$ are coefficients related to the reaction order. Following Itoh (Itoh et al., 2006), the methane conversion rate $x$ is determined by the outlet quantity and can be calculated as

$$
x=\left(x_{\mathrm{CO}}+x_{\mathrm{CO}_{2}}\right) /\left(x_{\mathrm{CH}_{4}}+x_{\mathrm{CO}}+x_{\mathrm{CO}_{2}}\right)
$$

The shift reaction occurs very quickly and therefore the conversion rate can be estimated from the equilibrium equation

$$
K_{\mathrm{sh}}(x-y)(S C-x-y)=y \cdot(3 x+y)
$$

where: $K_{\mathrm{sh}}=\exp [-\Delta G /(R \cdot T)], \Delta G$ is the change of the standard Gibbs free energy of the shift reaction in $\mathrm{J} / \mathrm{mol}, R$ is the universal gas constant in $\mathrm{J} /(\mathrm{mol} \cdot \mathrm{K})$ and $T$ is the reaction temperature in $\mathrm{K}$. Because the reaction constant does not depend on the $S C$ and $N C$ ratios, reaction order $a$ and $b$ can be found. $k$ will be constant if $a$ and $b$ are set correctly. The real values of $a$ and $b$ are those that result in the smallest $k$ deviation for different $S C$ and $N C$ ratios. Eqn (10) was solved numerically for various values of $a$ and $b$ and for the different $S C$ and $N C$ ratios (experimental conditions listed in Table 3).

Table 3. Experimental conditions (Fig. 3 and Fig. 4).

\begin{tabular}{c|ccc} 
Case & $\mathbf{C H}_{\mathbf{4}}$ & $\mathbf{N}_{\mathbf{2}}$ & $\mathbf{H}_{\mathbf{2}} \mathbf{O}$ \\
\hline No. & $\mathrm{mol} / \mathrm{min}$ & $\mathrm{mol} / \mathrm{min}$ & $\mathrm{mol} / \mathrm{min}$ \\
\hline 1 & $2.04 \cdot 10^{-3}$ & $6.13 \cdot 10^{-3}$ & $6.13 \cdot 10^{-3}$ \\
2 & $1.51 \cdot 10^{-3}$ & $9.03 \cdot 10^{-3}$ & $3.76 \cdot 10^{-3}$ \\
3 & $1.43 \cdot 10^{-3}$ & $5.72 \cdot 10^{-3}$ & $7.15 \cdot 10^{-3}$ \\
4 & $2.04 \cdot 10^{-3}$ & $4.09 \cdot 10^{-3}$ & $8.17 \cdot 10^{-3}$ \\
5 & $2.86 \cdot 10^{-3}$ & $2.86 \cdot 10^{-3}$ & $8.58 \cdot 10^{-3}$
\end{tabular}

The range from -1.0 to 2.0 was chosen as a common range for reaction order according to previously published data; Figure 3 shows the results of computation.

Based on results presented in Figure 4, orders of reaction were selected. The smallest reaction constant deviation for Ni/YSZ was found to be $a=0.98, b=-0.09$ (Fig. $3 \mathrm{a}$ ), and the smallest reaction constant deviation for $\mathrm{Ni} / \mathrm{SDC}$ was found to be $\mathrm{a}=0.98, b=-0.25$ (Fig. 3b), respectively. To develop a full kinetic model of the reforming reaction on the $\mathrm{Ni} / \mathrm{YSZ}$ and $\mathrm{Ni} / \mathrm{SDC}$ catalysts, the relationship between the reaction temperature and reaction constant was investigated. The effect of the temperature on the reaction was studied by increasing the temperature from $600^{\circ} \mathrm{C}$ to $750^{\circ} \mathrm{C}$. Based on experimentally obtained data, the reaction constant was calculated using Eqn (10).

Following Achenbach and Riensche (1994), the experiment was conducted for several different $S C$ and $N C$ ratios (experimental conditions are listed in the Table 3).
Reaction kinetics do not depend on $S C$ and $N C$, so to obtain more precise results a straight line was fitted to results collected for several different $S C$ and $N C$ ratios. The effect of the temperature on the reaction was studied by increasing the temperature stepwise (see Figure 4). The results of the experiment are presented as an Arrhenius plot, as shown in Figure 4. To estimate the quality of measured data the rules of propagation of uncertainty has been applied.

A straight line was fitted to the experimental data as a result of approximation. The equation for the straight line for this experiment takes a form of Arrhenius equation and can be described

a)

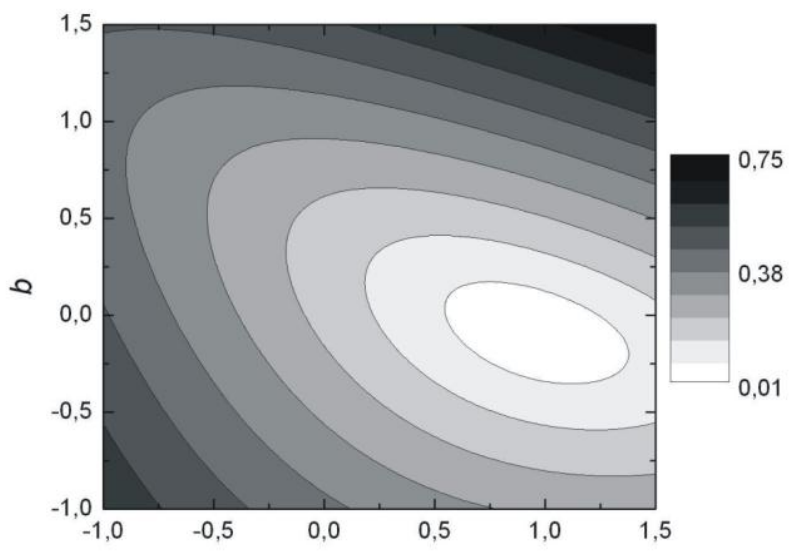

b)

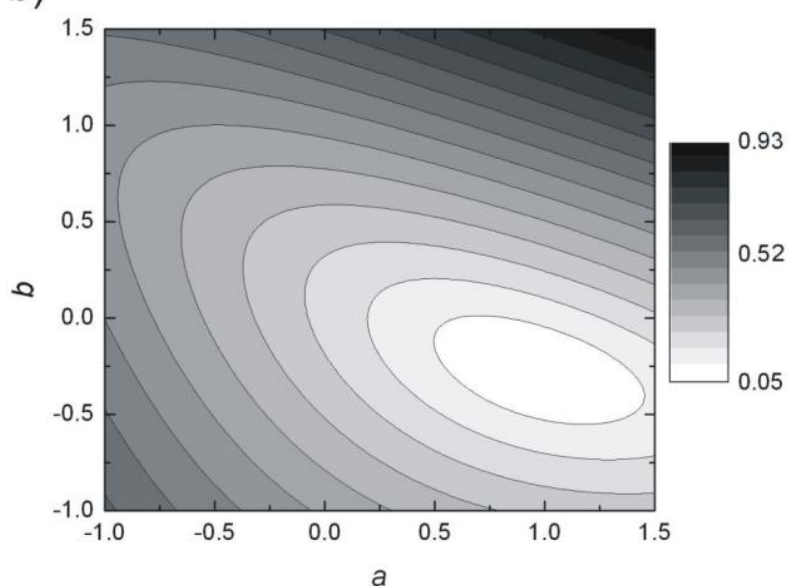

Figure 3. Relative standard deviation of $k$ measured at 650 ${ }^{\circ} \mathrm{C}$ for five different experimental condition listed in the Table 3 a) $\mathrm{Ni} / \mathrm{YSZ}$ b) $\mathrm{Ni} / \mathrm{SDC}$.

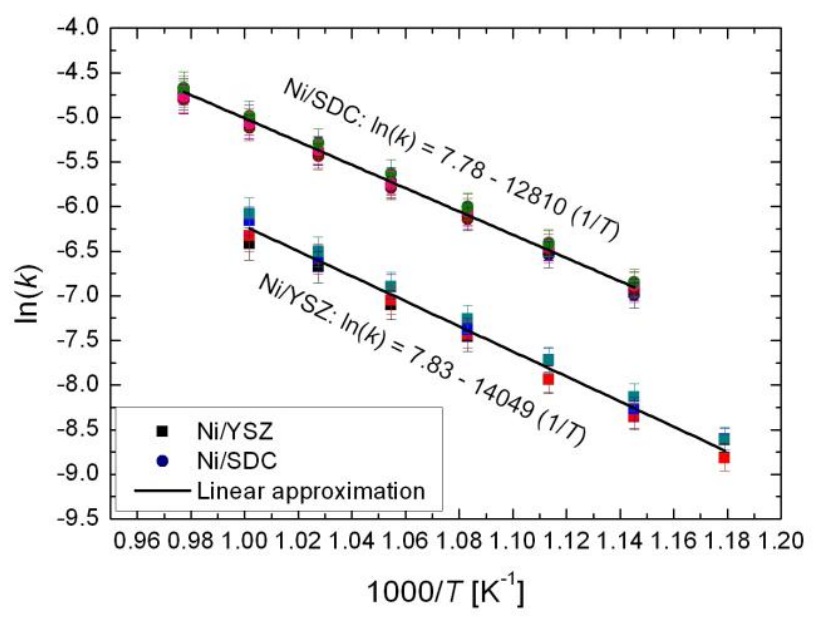

Figure 4. Arrhenius plot for Ni/YSZ and Ni/SDC. 
$\ln k=\ln A-(E / R) \cdot(1 / T)$

where $T$ is the temperature of fuel conversion in $\mathrm{K}, R=$ $8.314472 \mathrm{~J} /(\mathrm{mol} \cdot \mathrm{K})$ the universal gas constant, $A$ is called the pre-exponential factor and corresponds to the intercept of line at $1 / T=0$ and $E$ in $\mathrm{J} / \mathrm{mol}$, which is obtained from the slope of the line and provides the activation energy of the steam reforming reaction. Thus the kinetic of the methane/steam reforming reaction can be described by a reforming rate $R \mathrm{~mol} /\left(\mathrm{s} \cdot \mathrm{m}^{3}\right)$ based on the experimentally obtained data by following this equation:

$$
R_{\mathrm{st}}=w_{\text {cat }}^{\prime} A \exp (-E /(R T)) \cdot p_{\mathrm{CH}_{4}}^{a} \cdot p_{\mathrm{H}_{2} \mathrm{O}}^{b}
$$

Eqn (14) is based on experimental data, where $w^{\prime}$ cat is the catalyst density in $\mathrm{g} / \mathrm{m}^{3}, T$ in $\mathrm{K}$ is the temperature of the fuel conversion, $R$ is universal gas constant $\mathrm{J} /(\mathrm{mol} \cdot \mathrm{K})$, $E=116805 \mathrm{~J} / \mathrm{mol}$ or $E=106451 \mathrm{~J} / \mathrm{mol}$ is the activation energy of the fuel reforming reaction for $\mathrm{Ni} / \mathrm{YSZ}$ and $\mathrm{Ni} / \mathrm{SDC}$, respectively, $A_{\mathrm{st}}=2514 \mathrm{~mol} /\left(\mathrm{g} \mathrm{min}^{\mathrm{bar}}{ }^{\mathrm{a}+\mathrm{b}}\right)=41.5$ $\mathrm{mol} /\left(\mathrm{g} \mathrm{s} \mathrm{bar}^{\mathrm{a}+\mathrm{b}}\right), A_{\mathrm{st}}=2392 \mathrm{~mol} /\left(\mathrm{g} \mathrm{min} \mathrm{bar}^{\mathrm{a}+\mathrm{b}}\right)=40 \mathrm{~mol} /(\mathrm{g} \mathrm{s}$ $\mathrm{bar}^{\mathrm{a}+\mathrm{b}}$ ) is the pre-exponential factor for Ni/YSZ and Ni/SDC, respectively, $p_{\mathrm{CH} 4}$ is the partial pressure of methane $\mathrm{Pa}$ and $p_{\mathrm{H} 20}$ is the partial pressure of steam $\mathrm{Pa}$ and $a$ and $b$ are the dimensionless coefficients responding to the reaction order (also indicated in Table 4). It was previously reported by Tsang et al. (1995) that SDC is able to convert methane to synthetic gas; therefore Eqn (14) describes not only the reaction rate on nickel catalyst but also the reaction rate on co-catalyst SDC. Eqn (14) is an effective equation for describing the total reaction rate on bi-catalytic $\mathrm{Ni} / \mathrm{SDC}$ material.

Table 4. Kinetic data.

\begin{tabular}{c|cccc} 
Type & $\boldsymbol{E}$ & $\boldsymbol{A}_{\text {st }}$ & $\boldsymbol{a}$ & $\boldsymbol{b}$ \\
\hline & $\mathrm{J} / \mathrm{mol}$ & $\mathrm{mol} /\left(\mathrm{g} \mathrm{s} \mathrm{bar}^{\mathrm{a}+\mathrm{b}}\right)$ & - & - \\
\hline $\mathrm{Ni} / \mathrm{YSZ}$ & 116805 & 41.4 & 0.98 & -0.09 \\
$\mathrm{Ni} / \mathrm{SDC}$ & 106451 & 40 & 0.98 & -0.25
\end{tabular}

\section{Mathematical model of the biogas reforming process}

In the reforming process of biogas, there are three dominant reactions (Nishino and Szmyd, 2010):

Methane/steam reforming reaction

$\mathrm{CH}_{4}+\mathrm{H}_{2} \mathrm{O} \rightarrow 3 \mathrm{H}_{2}+\mathrm{CO}$

Dry reforming reaction

$$
\mathrm{CH}_{4}+\mathrm{CO}_{2} \rightarrow 2 \mathrm{H}_{2}+2 \mathrm{CO}
$$

Shift reaction

$$
\mathrm{CO}+\mathrm{H}_{2} \mathrm{O} \rightleftarrows \mathrm{H}_{2}+\mathrm{CO}_{2}
$$

The steam reforming reaction described by Eqn (15) is a slow and highly endothermic one; therefore a kinetic expression is required to calculate the reaction rate. The reaction rate of the methane/steam reforming reaction was described by an empirical Eqn (14). First detailed kinetics studies on dry reforming on nickel foil has been conducted by Temkin and co-workers (Bodrov et al., 1967). Bodrov et al. found that results fit the expression proposed previously for steam reforming (Bodrov et al., 1967). In recent studies Wei and Iglesia (2004) have suggested that the steam reforming of $\mathrm{CH}_{4}$ (15) and the dry reforming of $\mathrm{CH}_{4}$ (16) are mechanistically equivalent to the decomposition reaction of $\mathrm{CH}_{4}$. It was postulated and confirmed via experiment that a catalytic sequence, intrinsic kinetics and even that the mechanisms are equivalent for reactions (15) and (16). Therefore the effective rate of both dry reforming and methane steam reforming can be described by this equation:

$$
R_{e}=w_{\text {cat }}^{\prime} \cdot A \cdot \exp \left(\frac{-E}{R T}\right) \cdot p_{\mathrm{CH}_{4}}^{a}\left(p_{\mathrm{H}_{2} \mathrm{O}}+p_{\mathrm{CO}_{2}}\right)^{b}
$$

In the presented study, the separated rates of methane/steam reforming and dry reforming were distinguish by the assumption that rates of dry reforming and methane/steam reforming are proportional to the partial pressures of steam and carbon dioxide, respectively. The rates of dry and steam reforming can therefore be calculated as

$$
\begin{aligned}
& R_{\mathrm{dry}}=R_{\mathrm{e}} \frac{p_{\mathrm{CO}_{2}}}{p_{\mathrm{CO}_{2}}+p_{\mathrm{H}_{2} \mathrm{O}}} \\
& R_{\mathrm{st}}=R_{\mathrm{e}} \frac{p_{\mathrm{H}_{2} \mathrm{O}}}{p_{\mathrm{CO}_{2}}+p_{\mathrm{H}_{2} \mathrm{O}}}
\end{aligned}
$$

The shift reaction (17) is very fast reaction therefore the conversion rate can be estimated from the equilibrium equation:

$$
R_{\mathrm{sh}}=K_{\mathrm{sh}}^{+} p_{\mathrm{CO}} p_{\mathrm{H}_{2} \mathrm{O}}-K_{\mathrm{sh}}^{-} p_{\mathrm{H}_{2}} p_{\mathrm{CO}_{2}}
$$

where

$K_{\mathrm{sh}}=\frac{K_{\mathrm{sh}}^{+}}{K_{\mathrm{sh}}^{-}}=\frac{\left(p_{\mathrm{CO}_{2}} p_{\mathrm{H}_{2}}\right)}{\left(p_{\mathrm{CO}} p_{\mathrm{H}_{2} \mathrm{O}}\right)}=\exp \left(-\frac{\Delta G_{\mathrm{sh}}^{0}}{R T}\right)$

From the stoichiometry of reactions (15), (16) and (17), the partial pressures can be defined as follows:

$$
p_{\mathrm{H}_{2}}=\left(\frac{n_{\mathrm{H}_{2}}}{n_{\mathrm{all}}}\right) \cdot P=\left(\frac{3 x+y+2 z}{1+S C+C C+2 x+2 z}\right) \cdot P
$$

$$
p_{\mathrm{H}_{2} \mathrm{O}}=\left(\frac{n_{\mathrm{H}_{2} \mathrm{O}}}{n_{\text {all }}}\right) \cdot P=\left(\frac{S C-x-y}{1+S C+C C+2 x+2 z}\right) \cdot P
$$

$$
p_{\mathrm{CO}_{2}}=\left(\frac{n_{\mathrm{CO}_{2}}}{n_{\mathrm{all}}}\right) \cdot P=\left(\frac{C C+y-z}{1+S C+C C+2 x+2 z}\right) \cdot P
$$

$p_{\mathrm{CO}}=\left(\frac{n_{\mathrm{CO}}}{n_{\mathrm{all}}}\right) \cdot P=\left(\frac{x-y+2 z}{1+S C+C C+2 x+2 z}\right) \cdot P$

Introducing Eqns (22), (23), (24) and (25) into Eqn (21) yields the shift reaction equilibrium equation in the presence of dry reforming:

$(x-y+2 z)(S C-x-y) \cdot K_{\mathrm{sh}}=(C C+y-z)(3 x+y+2 z)$ 
The outlet composition per 1 mole of methane can be calculated from the stoichiometry of reactions (15), (17) and (16). The molar flow rate of each chemical component participating in the fuel reforming process in the reformer can be expressed by assuming $x$ as the conversion rate of methane/steam reforming reaction denoted as $y$; as the rate of $\mathrm{CO}$ consumed by the steam shifting reaction and $z$ as the conversion rate of $\mathrm{CH}_{4}$ through the dry reforming reaction (see Table 5). Variations of the molar flow rate of carbon monoxide, denoted as $x-y+2 z$, are produced by the fuel reforming reaction and dry reforming and consumed by the steam shifting reaction (see Table 5). Thus the mole fraction of each chemical species caused by the methane/steam reforming reaction, dry reforming and shift reaction are calculated as follows:

$$
\begin{aligned}
& m_{\mathrm{CH}_{4}}=(1-x-z) /(1+S C+C C+2 x+2 z) \\
& m_{\mathrm{H}_{2}}=(3 x+y+2 z) /(1+S C+C C+2 x+2 z) \\
& m_{\mathrm{H}_{2} \mathrm{O}}=(S C-x-y) /(1+S C+C C+2 x+2 z) \\
& m_{\mathrm{CO}}=(x-y+2 z) /(1+S C+C C+2 x+2 z) \\
& m_{\mathrm{CO}_{2}}=(C C+y-z) /(1+S C+C C+2 x+2 z)
\end{aligned}
$$

Table 5. Changes of chemical components inside the fuel reformer.

\begin{tabular}{l|lllll} 
& Inlet & Steam & Shift & Dry & outlet \\
\hline $\mathrm{CH}_{4}$ & 1 & $-x$ & 0 & $-z$ & $1-x-z$ \\
$\mathrm{H}_{2} \mathrm{O}$ & $\mathrm{SC}$ & $-x$ & $-y$ & 0 & $S C-x-y$ \\
$\mathrm{H}_{2}$ & 0 & $3 x$ & $Y$ & $2 z$ & $3 x+y+2 z$ \\
$\mathrm{CO}$ & 0 & $x$ & $-y$ & $2 z$ & $x-y+2 z$ \\
$\mathrm{CO}_{2}$ & $\mathrm{CC}$ & 0 & $Y$ & $-z$ & $C C+y-z$
\end{tabular}

\section{Results}

Numerical simulation is a useful tool for designing SOFC reformer processes. In the numerical model presented in this paper, gas composition at the outlet of the reformer can be predicted based on the inlet conditions (see Table 6). Examples of numerical results and their comparison with the experimental data are shown in Figures 5, 6, 7 and 8. In the present paper, the effect of the temperature on the steam reforming reaction was studied by increasing reaction temperature from $650^{\circ} \mathrm{C}$ to $750^{\circ} \mathrm{C}$. The biogas fed into the reformer was assumed to be composed of $\mathrm{CH}_{4}$ and $\mathrm{CO}_{2}$ and the molar percentage of $\mathrm{CO}_{2}$ contained in the biogas was varied in a range from $10 \%$ to $50 \%$ (see Figures 5 and 6). It was also assumed that the biogas was fed into the reformer with a steam-to-methane ratio of 3 . The data shows the outlet dry gas composition to be a function of reaction temperature. Figures 5 and 6 show a comparison of the outlet dry gas composition reacted on Ni/YSZ catalyst, Figures 7 and 8 show the one reacted on $\mathrm{Ni} / \mathrm{SDC}$ catalyst. As observed in Figures 5 and 6 , the amount of carbon monoxide increases along with the reaction temperature. This observation is significant because, in contrast to the low-temperature fuel cell, the carbon monoxide does not poison the high-temperature solid oxide fuel cell anode but can be electrochemically converted as a fuel (Achenbach and Riensche, 1994). The points situated on the lines show a perfect fit between experimental and numerical results. Most of the points are located on the line or close to it especially for low carbon dioxide concentration. This can indicate that there is future
Table 6. Experimental conditions (Figures 5 - 8).

\begin{tabular}{c|ccc} 
Case & $\mathbf{C H}_{\mathbf{4}}$ & $\mathbf{C O}_{\mathbf{2}}$ & $\mathbf{H}_{\mathbf{2}} \mathbf{O}$ \\
\hline & $\mathrm{mol} / \mathrm{min}$ & $\mathrm{mol} / \mathrm{min}$ & $\mathrm{mol} / \mathrm{min}$ \\
\hline $\mathrm{A}$ & & & \\
$\mathrm{b}$ & & & \\
$\mathrm{c}$ & $3.07 \cdot 10^{-3}$ & $3.07 \cdot 10^{-4}$ & $1.23 \cdot 10^{-2}$ \\
$\mathrm{~d}$ & $3.07 \cdot 10^{-3}$ & $6.13 \cdot 10^{-4}$ & $1.23 \cdot 10^{-2}$ \\
$\mathrm{e}$ & $3.07 \cdot 10^{-3}$ & $9.20 \cdot 10^{-4}$ & $1.23 \cdot 10^{-2}$ \\
& $3.07 \cdot 10^{-3}$ & $12.26 \cdot 10^{-4}$ & $1.23 \cdot 10^{-2}$ \\
& $3.07 \cdot 10^{-3}$ & $15.33 \cdot 10^{-4}$ & $1.23 \cdot 10^{-2}$
\end{tabular}
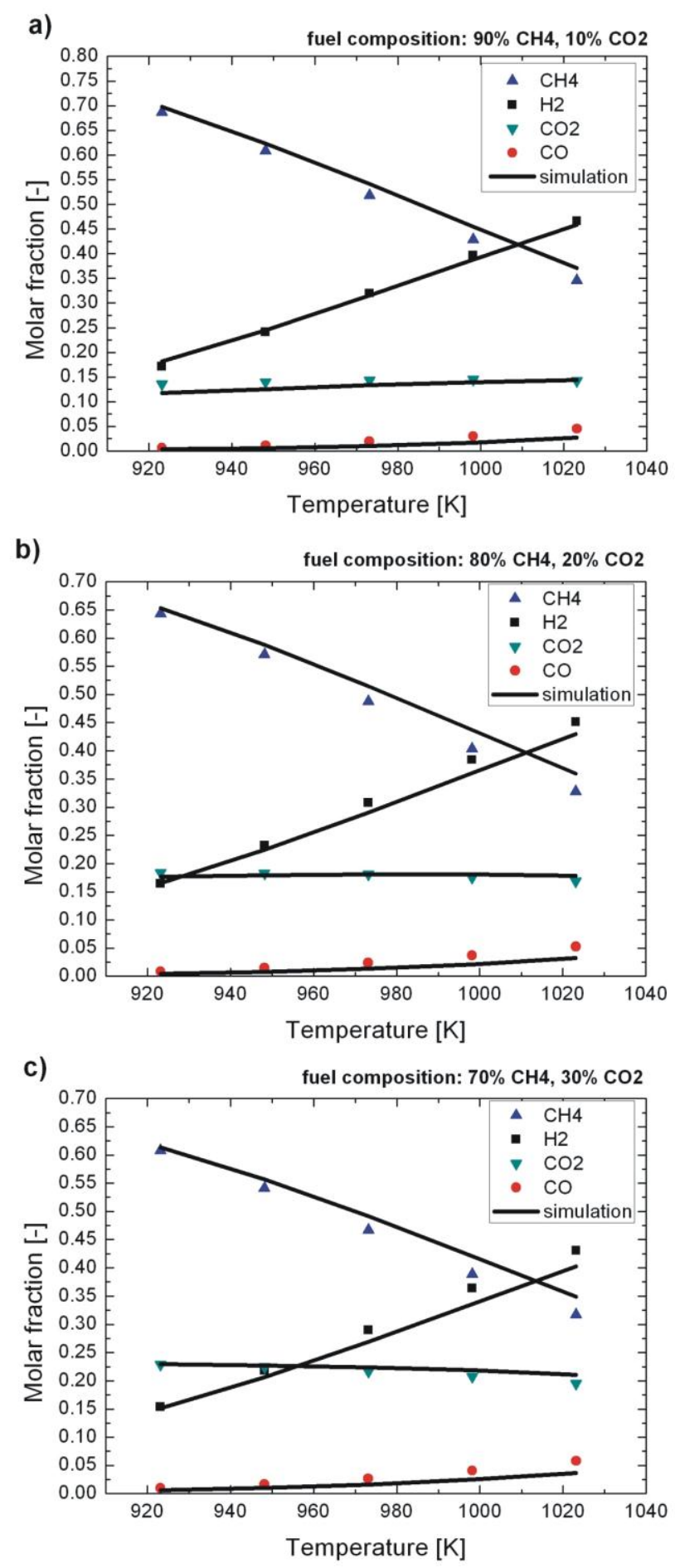

Figure 5. Experimental results compared to numerical simulation for Ni/YSZ for different fuel composition. a) $10 \%$ $\mathrm{CO}_{2} 90 \% \mathrm{CH}_{4}$ b) $20 \% \mathrm{CO}_{2} 80 \%$ c) $\mathrm{CH}_{4} 30 \% \mathrm{CO}_{2} 70 \% \mathrm{CH}_{4}$. 
d)

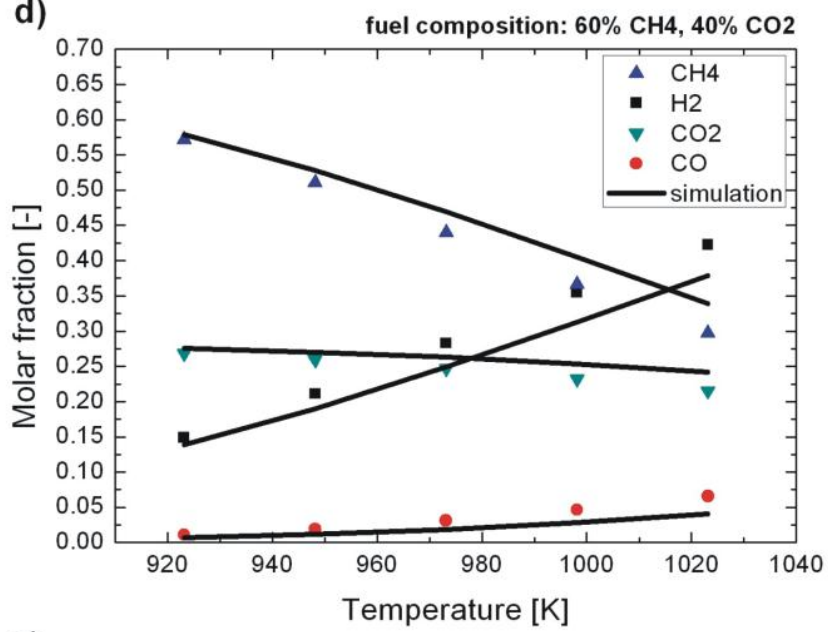

e)

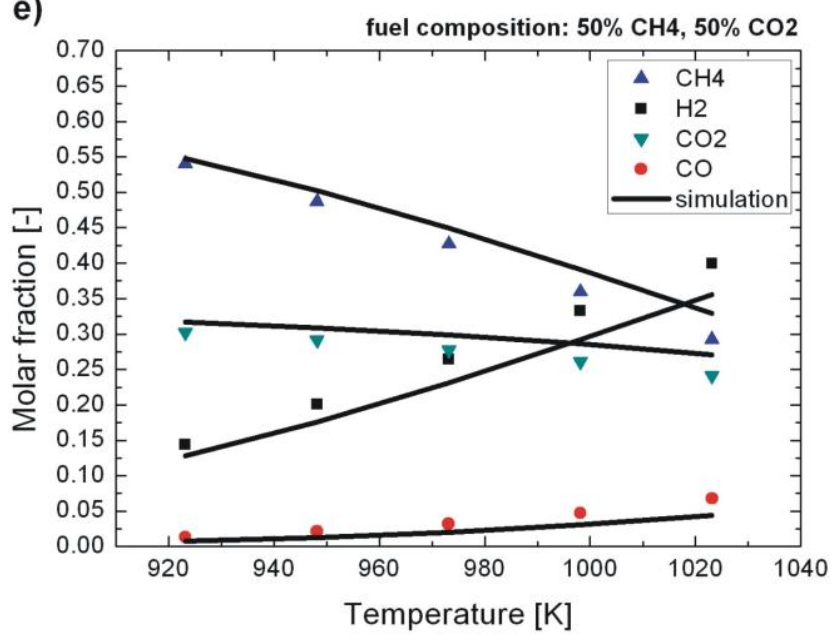

Figure 6. Experimental results compared to numerical simulation for Ni/YSZ for different fuel composition. d) $40 \%$ $\mathrm{CO}_{2} 60 \% \mathrm{CH}_{4}$ e) $50 \% \mathrm{CO}_{2} 50 \% \mathrm{CH}_{4}$.

need for deriving a proper kinetic equation for dry reforming of methane.

However, the presented plots indicated that the quality of the numerical model is satisfactory in most of the cases and can be used to predict the outlet gas composition for the methane/steam reforming process.

\section{Conclusions}

This paper has presented experimental and numerical studies on the fuel reforming process on $\mathrm{Ni} / \mathrm{YSZ}$ and $\mathrm{Ni} / \mathrm{SDC}$ catalysts. The gas mixture composition and the flow rate were measured at the outlet of the reformer to establish the methane reforming rate and kinetics of the reforming reaction. The experimental setup was built to investigate results for different thermal boundary conditions, the fuel flow rate and the steam-to-methane ratios. The reforming rate equation derived from experimental data was used in the mathematical model to predict the synthetic gas composition at the outlet of the reformer for the isothermal fuel reforming process of biogas. It was shown that the results of numerical computations fit the experimental data well. The obtained results show how important parallel, numerical and experimental studies are in the process design of SOFC reformers. It was also shown that applying a combined approach leads to the successful prediction of the outlet gas composition for different modeling conditions. a)

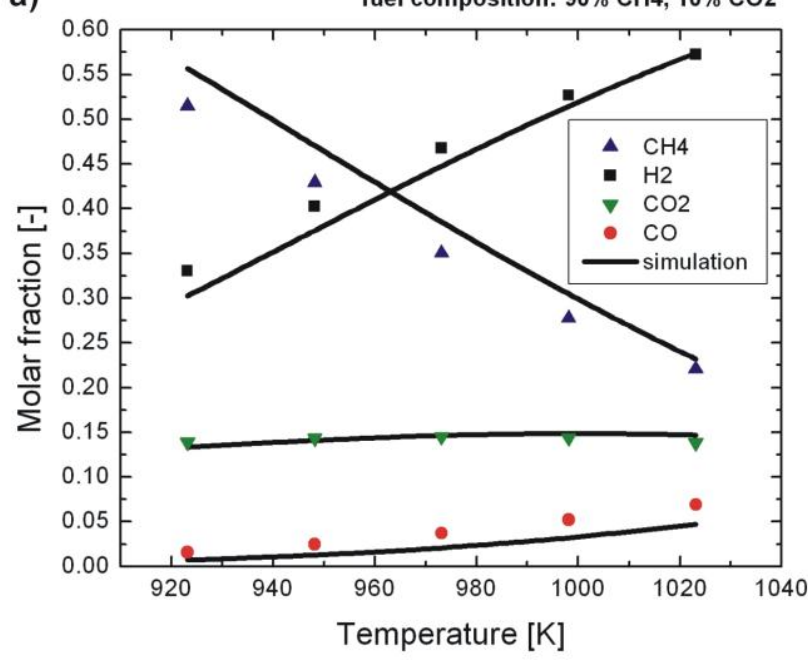

b)

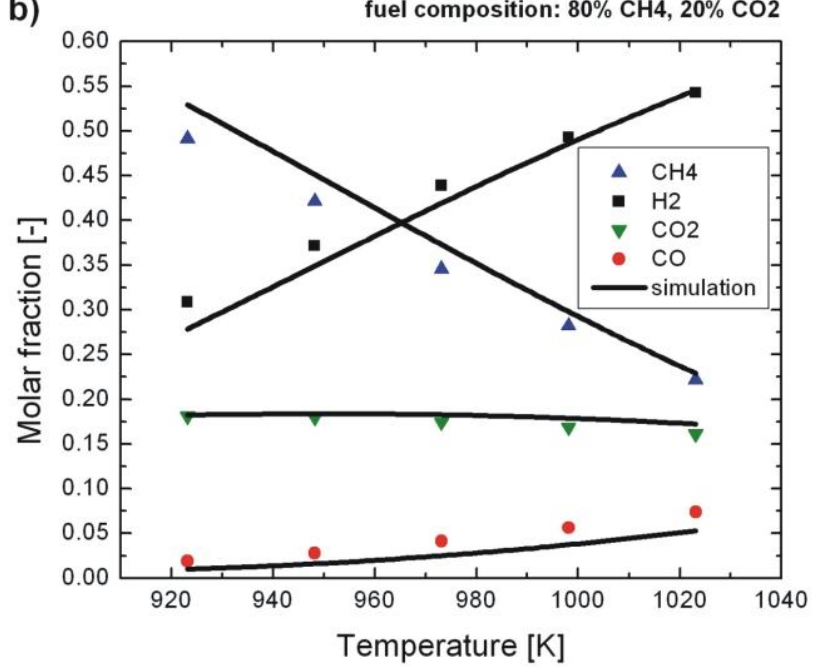

c)
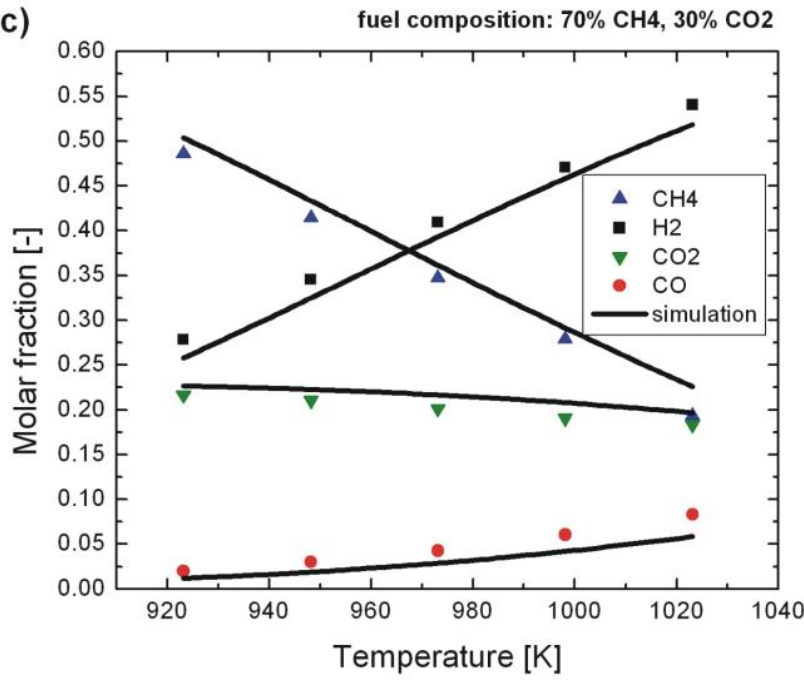

Figure 7. Experimental results compared to numerical simulation for $\mathrm{Ni} / \mathrm{SDC}$ for different fuel composition. a) $10 \%$ $\mathrm{CO}_{2} 90 \% \mathrm{CH}_{4}$ b) $20 \% \mathrm{CO}_{2} 80 \%$ c) $\mathrm{CH}_{4} 30 \% \mathrm{CO}_{2} 70 \% \mathrm{CH}_{4}$.

\section{Acknowledgments:}

This research was supported by the European Commission (project Dev-BIOSOFC, FP6-042436, MTKDCT-2006-042436) and by Polish Ministry of Science and High Education (Grant AGH No.11.11.210.198). 
d)

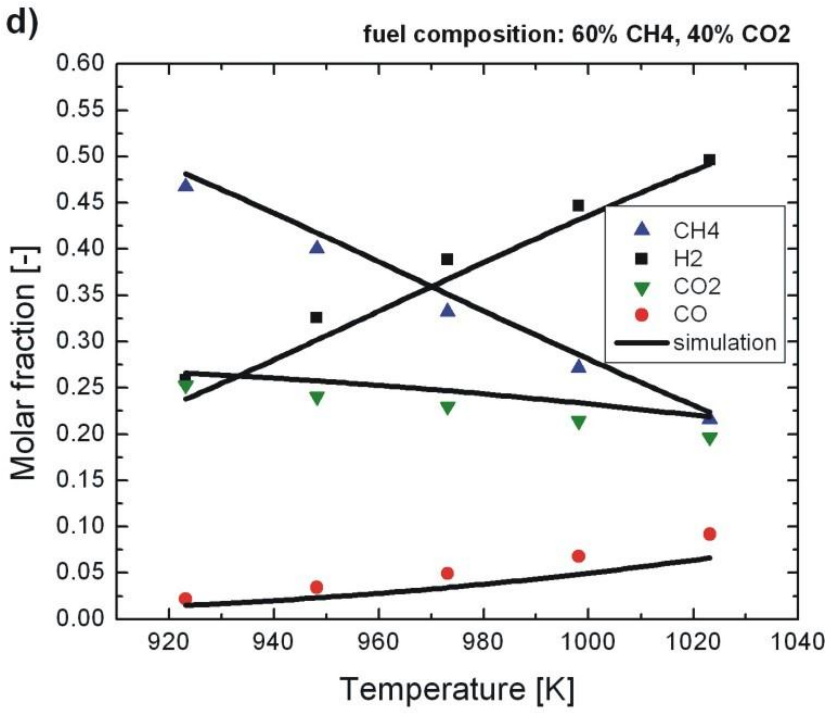

e)

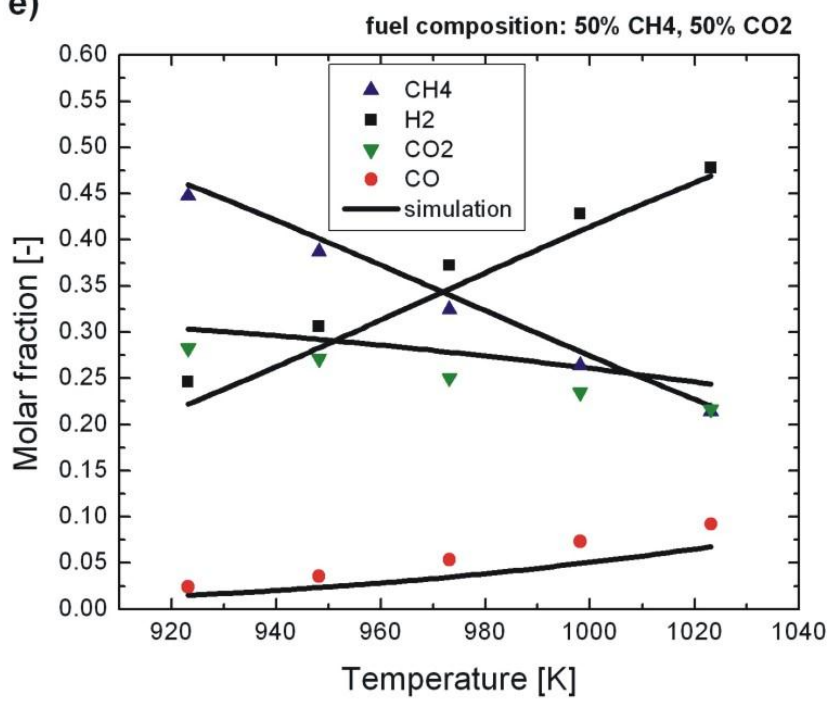

Figure 8. Experimental results compared to numerical simulation for Ni/SDC for different fuel composition. d) $40 \%$ $\mathrm{CO}_{2} 60 \% \mathrm{CH}_{4}$ e) $50 \% \mathrm{CO}_{2} 50 \% \mathrm{CH}_{4}$.

\section{Nomenclature}

a reaction order

A pre-exponential factor, (case dependent)

$b$ reaction order

CC carbon dioxide to methane ratio

E activation energy, J/mol

$F \quad$ molar flow rate, $\mathrm{mol} / \mathrm{min}$

$G \quad$ Gibbs free energy, $\mathrm{J} / \mathrm{mol}$

$K$ equilibrium constant

$k \quad$ reaction constant, (case dependent)

$m$ molar fraction

$N C \quad$ nitrogen to carbon ratio

$R \quad$ universal gas constants, $8.3144 \mathrm{~J} /(\mathrm{mol} \mathrm{K})$

$R_{\mathrm{i}} \quad$ reaction rate, $\mathrm{mol} /\left(\mathrm{s} \cdot \mathrm{m}^{3}\right)$

$r_{\mathrm{i}} \quad$ reaction rate, $\mathrm{mol} /(\mathrm{s} \cdot \mathrm{g})$

$P \quad$ pressure, $\mathrm{Pa}$

$S C$ steam to carbon ratio

$T$ temperature, $\mathrm{K}$

$u \quad$ velocity, $\mathrm{m} / \mathrm{s}$

$w \quad$ weigh of catalyst, $\mathrm{g}$

w' catalyst mass density, $\mathrm{g} / \mathrm{m}^{3}$ reforming

fraction of reacted carbon monoxide

fraction of reacted methane in dry reforming

Greek symbols

$\delta \quad$ oxygen nonstoichiometry

\begin{tabular}{ll}
\multicolumn{2}{l}{ Subscripts and superscripts } \\
all & all gases \\
eq & equilibrium \\
dry & dry reforming \\
e & effective \\
f & fluid \\
max & maximum value \\
min & minimum value \\
in & inlet condition \\
o & ambient \\
out & outlet condition \\
sh & shift reaction \\
st & steam reforming reaction
\end{tabular}

\section{References:}

Achenbach, E. and Riensche, E. 1994. Methane/steam reforming kinetics for solid oxide fuel cells. Journal of Power Sources. 1994, Vol. 49, pp. 333-348.

AGC SEMI CHEMICAL CO. 2009. Catalyst analysis sheets. 2009.

Berman, A., Karn, R.K. and Epstein, M. 2005. Kinetics of steam reforming of methane on $\mathrm{Ru} / \mathrm{Al} 2 \mathrm{O} 3$ catalyst promoted with Mn oxides. Applied Catalysis A: General 282 (2005) . 2005, Vol. 283, pp. 73-83.

Bodrov, I.M., Apel'baum, L.O. and Temkin, M.I. (1967) Kinetics of the reaction between methane and water varpour catalyzes by nickel on a porous support, Kinetika i Kataliz, Vol. 8, pp. 821-828.

Brandon, N. and Thompsett, D. 2005. Fuel Cells Compedium. Oxford : Elsevier, 2005.

Itoh, N., Yamamoto, T., Sato, T., Yu, W. and Ohmori, T. 2006. Kinetic analysis on low-temperature steam reforming of methane using a ruthenium supported catalyst. Journal of Japan Institute of Energy. 2006, Vol. 85, pp. 307-313.

Komatsu, Y., Kimijima, S. and Szmyd, J.S. 2009. A Performance Analysis of a Solid Oxide Fuel Cell - Micro Gas Turbine Hybrid System Using Biogas. ECS Transactions. 2009, Vol. 25 (2), p. 1061.

Molenda, J., Swierczek, K. and Zajac, W. 2007. Functional materials for the IT-SOFC. Journal of Power Sources. 2007, pp. 657-670.

Murray, E.P., Tsai, T. and Barnett, S.A. 1999. Adirectmethane fuel cell with a ceria-based anode. NATURE. 1999, Vol. 400.

Nishino, T. and Szmyd, J.S. 2010. Numerical Analysis of a cell-based indirect internal reforming tubular SOFC operating with biogas. Journal of Fuel Cell Science and Technology. 2010, Vol. 7, 051004, p. B1103. 
Staniforth, J. and Kendall, K. 1998. Biogas powering a small tubular solid oxide fuel cell. Journal of Power Sources, 1998, Vol. 71, pp. 275-277.

Thyberg, N.S. and Myrkn, C. 1995. Fuel processing of biogas for small fuel cell power. Journal of Power Sources. 1995, Vol. 56, pp. 45-49.

Tsang, S.C., Claridge, J.B. and Green, M.L.H. 1995. Recent advances in the conversion of methane to synthesis gas. Catalysis Today. 1995, Vol. 23, pp. 3-15.

Van Herle, J., Membrezb, Y. and Bucheli, O. 2004. Biogas as a fuel source for SOFC co-generators. Journal of Power Sources. 2004, Vol. 127, pp. 300-312.
Vannice, M.A. 2005. Kinetic of catalytic reactions. New York : Springer, 2005.

Wei, J. and Iglesia, E. 2004. Isotopic and kinetic assessment of the mechanism of reactions of $\mathrm{CH}_{4}$ with $\mathrm{CO}_{2}$ or $\mathrm{H}_{2} \mathrm{O}$ to form synthesis gas and carbon on nickel catalysts. 2004, Vol. 224, pp. 370-383.

$\mathrm{Xu}$, J. and Froment, G.F. 1989. Methane steam reforming; methanation and water-gas shift reaction I and II. AlChE Journal. 1989, Vol. 35, pp. 88-103. 